\title{
Regenerative potential and functional composition of soil seed banks in remnant evergreen broad-leaved forests under urbanization in South China
}

\author{
J. Wang ${ }^{1}$, L. Huang ${ }^{1,2}$, H. Ren ${ }^{1,4}$, Z. Sun ${ }^{1}$ and Q. Guo ${ }^{3}$ \\ ${ }^{1}$ Key Laboratory of Vegetation Restoration and Management of Degraded Ecosystems, South China Botanical Garden, \\ Chinese Academy of Sciences; Xingke Road 723, Tianhe District, Guangzhou 510650, China \\ 2 Guangdong Provincial Academy of Environmental Science, Dongfeng Middle Road 335, Yuexiu District, Guangzhou \\ 510045, China \\ ${ }^{3}$ USDA FS-Eastern Forest Environmental Threat Assessment Centre; 200 WT Weaver Blvd., Asheville, NC 28804, USA \\ ${ }^{4}$ Corresponding author. E-mail: renhai@scib.ac.cn; Tel : +8620-37252916; Fax: +8620-37252916
}

Keywords: Functional composition, Indigenous tree species, Natural regeneration, Remnant forest, Urbanization

\begin{abstract}
Soil seed banks can act as an important source in forest regeneration, and the information on the seed bank composition is vital for determining the resilience of plant communities under severe environments such as urban settings. In this study, we examined the seed bank density and functional composition, and their relationships with aboveground vegetation in three remnant evergreen broad-leaved forests, i.e., PuGang (PG), LuoGang (LG), and DaLingShan (DLS) under urbanization in Guangzhou, South China. In both years of our study (2010-2011), seed density and species richness for overall soil seed banks and each classified life forms (tree, shrub, herb and grass) significantly differed among the forests and were much higher in the PG forest. The prevailing life forms in the seed banks were herbs and grasses, and the proportion of tree species Importance Value index (IV) of the seed banks was low. We did not detect significant difference in the percentage of exotic species seeds in the seed banks among the forests. The proportion of species with animal dispersal mode was much higher in the DLS forest than in the PG and LG forests. The similarity in species composition between standing vegetation and seed banks was low with the lower value in the DLS forest than in PG and LG forest. Our findings suggest that the regeneration potential of the soil seed banks is limited for the remnant forests in urban areas. Therefore, greater proactive and enhanced conservation efforts are thus needed.
\end{abstract}

Nomenclature: Wu and Raven (1994).

Abberviations: IV-Importance Value, DLS- DaLingShan, LG- LuoGang, LSD-Least Significant Difference, PG- PuGang.

\section{Introduction}

Urban environmental issues are becoming paramount as a result of increased urbanization and the dependence of urban environments for sustaining life in big cities (Pedlowski et al. 2002). With rapid urbanization, the natural vegetation becomes highly fragmented. For this reason, natural forests within urban settings are receiving growing attention for their contribution to high values for biodiversity conservation, as well as for providing numerous ecosystem services (e.g., carbon sequestration and regulating microclimate) for urban citizens (Dwivedi et al. 2009, Heyman 2010). Despite their importance, however, many of these remnant forests are gradually becoming more isolated and restricted to smaller areas. As a consequence, the vegetation structure becomes simpler and poor in quality (Broshot 2007, Burton and Samuelson 2008). To conserve the diversity of these forests and ecosystem functions and services, greater and more efficient conservation efforts are needed (Grimm et al. 2008).
Evergreen broad-leaved forest is the zonal vegetation type in subtropical China, and plays a great role in biodiversity and sustainable development in the region (Wang et al. 2005). However, the extant evergreen broad-leaved forests are threatened in South China due to urban sprawl. Therefore, active managements are urgently needed to enhance the habitat value of remnant forests within the urban settings (Ding et al. 2004). Natural regeneration is a keystone process in sustainable forestry, and the related information is crucial to effective restoration managements (Bertoncini and Rodrigues 2008, Leinonen et al. 2008). Although cities in South China are growing extremely fast and will continue to grow, very little is known about the regeneration potential of the extant remnant evergreen broad-leaved forests under urbanization (Huang et al. 2012, 2013).

As a component of plant communities, soil seed banks may often be regarded as an important source in forest regeneration, but their role under certain conditions are not always clear (Wang et al. 2010, Koncz et al. 2011). Therefore, 
the knowledge of the soil seed banks is vital for determining the resilience of a plant community, because the seeds stored in the soil may recruit new seedlings when disturbance creates suitable environmental conditions (Dölle and Schmidt 2009). Seed bank composition depends on the seed storing conditions in the soil affected by biotic and abiotic factors such as predation, soil temperature, and litter mass on the floor (Maron and Simms 1997, Hill and French 2003, Wang et al. 2009). Urbanization related disturbances may influence these factors and thereby affect the seed bank composition (Kostel-Hughes et al. 1998). Furthermore, the aboveground vegetation in the community also directly influences the composition of soil seed banks. Therefore, knowing the relationship between seed banks and aboveground vegetation can be helpful in planning community in responses to disturbances (Bossuyt and Honnay 2008), Currently, many studies have focused on structure and diversity of aboveground community in the forest under urbanization, but soil seed banks have been overlooked (Pellissier et al. 2008, Huang et al. 2012).

In this study, we investigated the density and species composition of the soil seed banks in three evergreen broadleaved forests under urbanization in South China. Our main objectives were to determine the seed bank density, functional composition and its relationship with aboveground vegetation in the remnant natural forests, and also to evaluate the regenerative potential of the soil seed banks. Specifically, we sought to answer the following questions: (1) How do the size, species richness, diversity, and functional composition of soil seed banks differ among the three remnant forests under urbanization? (2) What are the similarities in species composition between the seed bank and aboveground vegetation? And (3) What are the roles of the soil seed banks in the regeneration of these remnant forests under urban settings?

\section{Materials and methods}

\section{Study sites}

The study area is located at Guangzhou $\left(112^{\circ} 57^{\prime}-114^{\circ} 3^{\prime} \mathrm{E}\right.$, $\left.22^{\circ} 26^{\prime}-23^{\circ} 56^{\prime} \mathrm{N}\right)$, the capital and the political and economical center of Guangdong province in South China. The total area of Guangzhou is about $7434 \mathrm{~km}^{2}$ and had a population of ca. 10 million in 2008. The area is characterized by a typical subtropical monsoon climate. The average annual temperature is about $21.5^{\circ} \mathrm{C}$ and has a distinct seasonal pattern. The annual precipitation ranges from $1370 \mathrm{~mm}$ to $1965 \mathrm{~mm}$ with a distinct wet season from April to September and the dry season from October to March. The potential zonal climax vegetation of the region is subtropical monsoon evergreen broadleaved forests. The soil type is lateritic red soil developed from granite and sand shales (Editorial Committee of Forests of Guangdong 2005). Guangzhou was selected as it is one of the largest cities in China representing a rapidly urbanizing landscape, with dense population, residential and commercial buildings, and high traffic volumes in the city center. Since the growth of urban sprawl in the late 1970s, the extent of the evergreen broad-leaved forests has decreased significantly due to long-term human disturbance such as deforestation.
Currently, these remnant forests are scattered in the urban setting, always in the form of preserved forests in natural reserves, village woodlands for sacred use, and scenic forests.

In this study, we selected three remnant evergreen broadleaved forest in this region, i.e., PuGang (PG), LuoGang (LG) and DaLingShan (DLS). The selected forests had a minimum stand age of 55 years and without intensive anthropogenic disturbances and forest management in recent decades, and occupied similar climate and soil type. The PG forest located in the urban area where occupied numerous industrial sites and residential buildings, and the dominant tree species include Schima superba, Acronychia pedunculata, and Syzygium hancei. The LG forest lied in the eastern suburb of Guangzhou with the dominant tree species of Cryptocarya concinna and Endospermum chinense. This forest was mainly surrounded by orchards, secondary forests and established plantations. The DLS forest was located in a rural area about $75 \mathrm{~km}$ from the city centre, and had dominant tree species such as Machilus chinensls, Castanopsis lamontii, and Castanopsis hystrix. For more information of these forests, see Huang et al. (2012).

\section{Soil sampling and vegetation survey}

To detect the seed bank composition, soil sampling was conducted in two consecutive years (April 2010 and April 2011). In each forest, three parallel transects $(10 \mathrm{~m} \times 50 \mathrm{~m}$ per transect) on the same slope were established $10 \mathrm{~m}$ apart. Each transect was divided into five plots $(10 \mathrm{~m} \times 10 \mathrm{~m})$ with a subplot $(1 \mathrm{~m} \times 1 \mathrm{~m})$ located at the centre of each quadrat. Six soil samples of $10 \times 10 \times 10 \mathrm{~cm}(\mathrm{~L} \times \mathrm{W} \times \mathrm{D})$ with litter intact were randomly and carefully excavated from each subplot in April 2010 and 2011, respectively. The soil samples were divided into two depth classes: $0-5 \mathrm{~cm}$ and $5-10 \mathrm{~cm}$. The six soil samples were pooled for each subplot and depth class. Totally, the soil sampling area in each forest was $0.9 \mathrm{~m}^{2}$.

Seed abundance and species composition in the seed banks were determined with germination assays following Ter Heerdt et al. (1996). Each soil sample was first passed through a $2-\mathrm{mm}$ sieve to remove coarse debris and then the soil particles were sieved with $0.2 \mathrm{~mm}$ again to eliminate soil clay components. Seeds with diameter $>2 \mathrm{~mm}$ were retrieved and then re-deposited in the final sieved soil samples. Each soil sample was placed in a seed germination tray with perforations on the bottom for drainage after placing a 2-cm-thick layer of heat-sterilized $\left(120^{\circ} \mathrm{C}\right.$ for $\left.10 \mathrm{~h}\right)$ sand to prevent the soil samples from becoming water-saturated. All germination trays were placed in an experimental greenhouse and watered daily. The mean temperature in the greenhouse was $28^{\circ} \mathrm{C}$, and the mean relative humidity was $66 \%$. Newly all germinated seedlings which were identified at the species level were counted and then removed from the seed trays every 2-5 days. Unidentified seedlings were transplanted into additional germination trays for further growth until the species could be identified. After the newly germinated seedlings were identified and removed, the soil in each tray was thoroughly stirred to stimulate germination of remaining viable seeds (Smith et al. 2002). Ten seed trays filled with sterilized sand only were 
kept under the same conditions as a control for seed contamination; no seedlings were found in these control trays. For the seed bank detection in each year, the germination assay was continued for about 6 months (April to October) and terminated when no new seedlings had emerged for 4 weeks (Wang et al. 2009).

For comparisons between the seed banks and aboveground vegetation, the coverage of each species was estimated visually in each plot. All vegetation surveys were completed right after soil sampling. Meanwhile, the biomass of standing leaf litter on the ground was also measured in each forest. In each plot, we randomly placed a subplot $(1 \mathrm{~m} \times 1 \mathrm{~m})$ to collect standing leaf litter. The leaf litters were oven-dried at $65^{\circ} \mathrm{C}$ to constant mass then weighted.

\section{Data analysis}

Seed density (no. of seeds $\mathrm{m}^{-2}$ ) was calculated from the number of emerged seedlings. Three biodiversity indices were calculated for the soil seed banks in each forest according to Shannon (1948): (1) Simpson index (D); (2) Shannon index $(H)$ and (3) Pielou index $(J)$. Importance Value (IV, \%) for each species in the soil seed banks was calculated as the average of relative abundance (i.e., the number of seeds of a species/the total number of seeds for all species $\times 100 \%$ ) and relative frequency (i.e., the proportion of subplots in the forest containing the given species $\times 100 \%$ ). The similarity in species composition between the soil seed banks and corresponding extant vegetation in each forest was measured using Sorensen similarity index (SI, \%) (Cox 1985).

Quantitative and qualitative differences in the seed banks, and the standing litter biomass of different forests were analyzed with one-way ANOVA. All data were $\log _{10}$ or arcsine square-root transformed when they did not satisfy normality assumptions. Least Significance Difference (LSD) were used for multiple comparison when ANOVAs were significant at $\alpha=0.05$. All statistical analyses were performed using SPSS 13.0 for Windows (SPSS software Inc., USA).

\section{Results}

\section{Standing leaf litter biomass}

We found significant differences in standing leaf litter biomass on the forest ground among the three remnant forests $(\mathrm{F}=23.968, \mathrm{P}<0.001)$. The standing leaf litter biomass in the PG forest $\left(665.8 \pm 25.4 \mathrm{~g} \mathrm{~m}^{-2}\right)$ was much higher than that in the LG forest $\left(430.5 \pm 31.2 \mathrm{~g} \mathrm{~m}^{-2}\right)$ and DLS forest (456.1 $\left.\pm 25.1 \mathrm{~g} \mathrm{~m}^{-2}\right)$.

\section{Seed abundance}

A total of 1631 and 1075 seedlings were recorded in the soil samples collected from the three remnant evergreen broad-leaved forests in 2010 and 2011, respectively. Seed bank density in the $0-10 \mathrm{~cm}$ soil layer differed significantly among the three forests in $2010(\mathrm{~F}=6.715, \mathrm{P}=0.001)$ and $2011(\mathrm{~F}=11.043, \mathrm{P}<0.001)$. In both years, seed bank density in the PG forest was much higher than that in the other two forests (Fig. 1a,b). The abundance of viable seeds in the upper 0-5 cm soil layer tended to be higher than the 5-10 cm layer, and significant difference was observed between the two soil layers in the LG forest in 2011 (Fig. 1b). No significant difference in seed bank density was observed for the PG and LG forests between 2010 and 2011, whereas the seed bank density in 2010 was much higher than that sampled in 2011 in the DLS forest $(\mathrm{P}=0.003)$.

\section{Species richness and diversity}

In the samplings conducted in both years, a total of 80 species (19 trees, 21 shrubs, 30 herbs, and 10 grasses) belonging to 32 families were detected from the soil seed banks in the three remnant forests. The total number of species in the seed banks at each forest varied from 25 to 31 in 2010, and from 29 to 39 in 2011, respectively (Appendix). Compared to the total number of species detected in each forest in 2010, the values in 2011 were relatively higher (Appendix). The major-
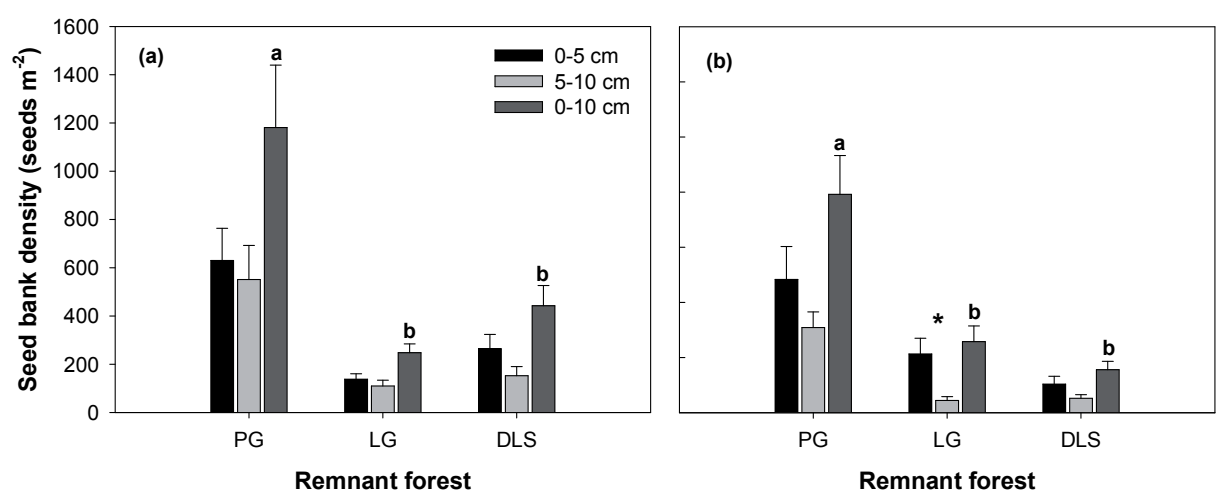

Figure 1. The seed density ( forests in 2010 and 2011, respectively. Seed densities marked with different letters $(\mathrm{a}, \mathrm{b})$ indicate that they were significantly different from each other, whereas an asterisk indicates significant difference $(\mathrm{P}<0.05)$ between the upper $(0-5 \mathrm{~cm})$ and lower $(5-10 \mathrm{~cm})$ soil layers at the same site, based on the results from LSD test after one-way ANOVA. 
2010

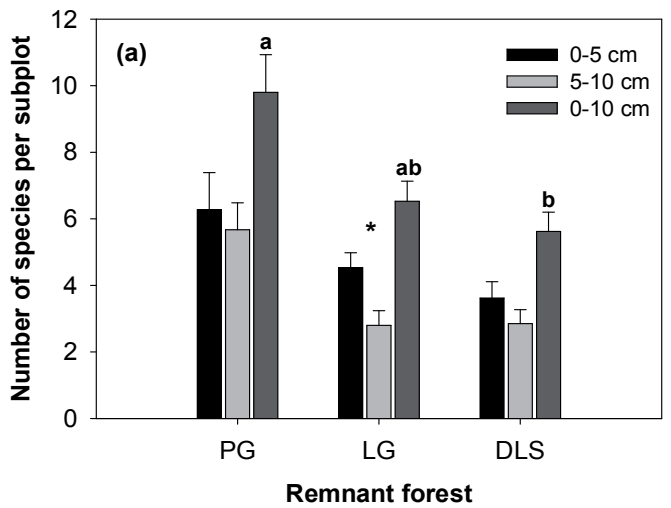

2011

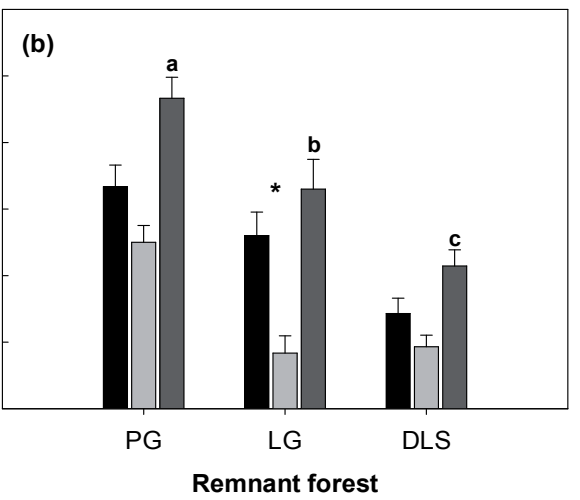

Figure 2. Number of species per plot (mean \pm SE) in the soil seed banks of the three remnant forests in 2010 and 2011 , respectively. Different lowercase letters above the bars indicate significant difference $(\mathrm{P}<0.05)$ between different sites, whereas an asterisk indicates significant difference $(\mathrm{P}<0.05)$ between the upper $(0-5 \mathrm{~cm})$ and lower $(5-10 \mathrm{~cm})$ soil layers at the same site, based on the results from LSD test after one-way ANOVA.
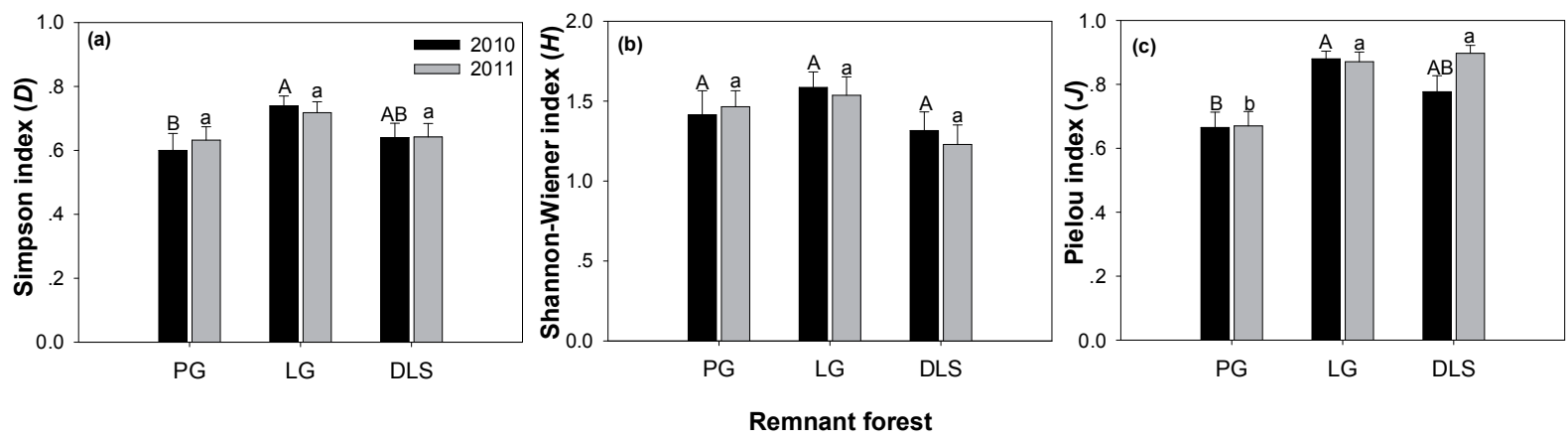

Figure 3. Simpson index $(D)$, Shannon-Wiener index $(H)$, and Pielou index $(J)$ of the soil seed banks $(\mathrm{mean} \pm \mathrm{SE})$ in the three remnant forests in 2010 and 2011, respectively. Different uppercase, and lowercase letters above bars indicate significant difference $(\mathrm{P}<0.05)$ between different forests in 2010 and 2011, respectively, based on the results from LSD test after one-way ANOVA.

ity of species detected from the soil seed banks appeared in the $0-5 \mathrm{~cm}$ soil layers, and many species were only found in the upper soil layer. In the soil seed banks of PG, LG, and DLS forest, the upper soil layers comprised nearly $77.4,92.0$ and $68.0 \%$ of the total number of detected species in 2010, and $84.6,86.5$ and $75.9 \%$ of the total number of detected species in 2011, respectively (data not shown).

The mean number of species per subplot differed significantly among the studied forests in $2010(\mathrm{~F}=6.44, \mathrm{P}=0.001)$ and $2011(\mathrm{~F}=8.812, \mathrm{P}<0.001)$. Species richness per subplot in the PG forest was much higher than that in the DLS forest in 2010, and also higher than that in the LG and DLS forests in 2011, respectively (Fig. 2a,b). Similar to the vertical distribution pattern in seed abundance, the mean number of species per subplot also relatively high in the upper soil layer, with significant differences found in the LG forest in 2010 and 2011 (Fig. 2a,b). In all the three remnant forests, there was no significant difference in species richness per subplot between 2010 and $2011(\mathrm{P}>0.05)$.

Significant differences in Pielou index $(J)$ were observed among the three forests in both $2010(\mathrm{~F}=6.931, \mathrm{P}=0.003)$ and $2011(\mathrm{~F}=13.024, \mathrm{P}<0.001) . J$ values of the seed bank in the LG and DLS forests were much higher than that in the PG forest (Fig. 3c). The seed bank of the PG forest had a lower Simpson index $(D)$ than the LG forest in 2010 (Fig. 3a). No significant difference in Shannon-Wiener index $(H)$ was observed among the forests in both years (Fig. 3b).

\section{Functional groups in the seed banks}

Seed abundance and species richness per subplot for trees, shrubs and grasses in the PG forest were much higher than that in the LG and DLS forests in 2010 (Table 1). However, for herbaceous species, the seed abundance was much higher in the DLS forest compared to the other two forests. In 2011, the seed abundance and species richness per plot in all the classified life forms tended to be higher in the PG forest (Table 1).

The dominant life form in the soil seed banks were herbs and grasses, and the tree species represented no more than $32 \%$ of the total number of species in the seed banks of each forest (Appendix). The majority of the seeds and the species 
Table 1. Seed abundance and species richness per subplot of different life forms in the soil seed banks of the three remnant forests in 2010 and 2011. Values are mean \pm SE per subplot, and the results are based on one-way ANOVA followed by LSD test.

\begin{tabular}{|c|c|c|c|c|c|c|c|}
\hline & \multirow[t]{2}{*}{ Life form } & \multicolumn{3}{|c|}{2010} & \multicolumn{3}{|c|}{2011} \\
\hline & & PG & LG & DLS & PG & LG & DLS \\
\hline \multirow[t]{4}{*}{ Seed abundance } & Tree & $11.2 \pm 2.3 \mathrm{a}$ & $4.9 \pm 0.9 \mathrm{~b}$ & $3.1 \pm 1.5 \mathrm{~b}$ & $11.4 \pm 3.3 \mathrm{a}$ & $7.3 \pm 2.6 \mathrm{ab}$ & $1.9 \pm 0.5 \mathrm{~b}$ \\
\hline & Shrub & $2 . .5 \pm 0.6 \mathrm{a}$ & $0.5 \pm 0.2 b$ & $0.5 \pm 0.2 \mathrm{~b}$ & $3.3 \pm 1.0 \mathrm{a}$ & $2.6 \pm 1.0 \mathrm{a}$ & $1.6 \pm 0.4 \mathrm{a}$ \\
\hline & Herb & $6.9 \pm 1.6 \mathrm{~b}$ & $5.5 \pm 1.9 \mathrm{~b}$ & $15.7 \pm 4.7 \mathrm{a}$ & $6.2 \pm 1.3 \mathrm{a}$ & $3.5 \pm 1.0 \mathrm{a}$ & $3.6 \pm 1.6 \mathrm{a}$ \\
\hline & Grass & $50.2 \pm 14.1 \mathrm{a}$ & $4.0 \pm 1.0 \mathrm{~b}$ & $6.5 \pm 1.0 \mathrm{~b}$ & $26.6 \pm 7.7 \mathrm{a}$ & $2.0 \pm 0.6 \mathrm{~b}$ & $1.9 \pm 0.6 \mathrm{~b}$ \\
\hline \multirow[t]{4}{*}{ Species richness } & Tree & $2.6 \pm 0.4 \mathrm{a}$ & $2.1 \pm 0.3 \mathrm{a}$ & $0.8 \pm 0.2 \mathrm{~b}$ & $3.0 \pm 0.4 \mathrm{a}$ & $2.2 \pm 0.3 \mathrm{ab}$ & $1.3 \pm 0.3 \mathrm{~b}$ \\
\hline & Shrub & $1.5 \pm 0.3 \mathrm{a}$ & $0.5 \pm 0.2 b$ & $0.5 \pm 0.2 \mathrm{~b}$ & $1.7 \pm 0.3 \mathrm{a}$ & $1.6 \pm 0.4 \mathrm{a}$ & $0.9 \pm 0.3 \mathrm{a}$ \\
\hline & Herb & $3.3 \pm 0.6 \mathrm{a}$ & $2.5 \pm 0.3 \mathrm{a}$ & $2.9 \pm 0.4 \mathrm{a}$ & $2.5 \pm 0.3 \mathrm{a}$ & $1.8 \pm 0.4 \mathrm{ab}$ & $1.3 \pm 0.2 \mathrm{~b}$ \\
\hline & Grass & $2.2 \pm 0.2 \mathrm{a}$ & $1.5 \pm 0.3 b$ & $1.5 \pm 0.2 \mathrm{~b}$ & $2.0 \pm 0.2 \mathrm{a}$ & $1.0 \pm 0.3 \mathrm{~b}$ & $0.8 \pm 0.2 \mathrm{~b}$ \\
\hline
\end{tabular}

The values followed by different lowercase letters indicate significant difference $(\mathrm{P}<0.05)$ between different forests within the same life form in 2010 and 2011.

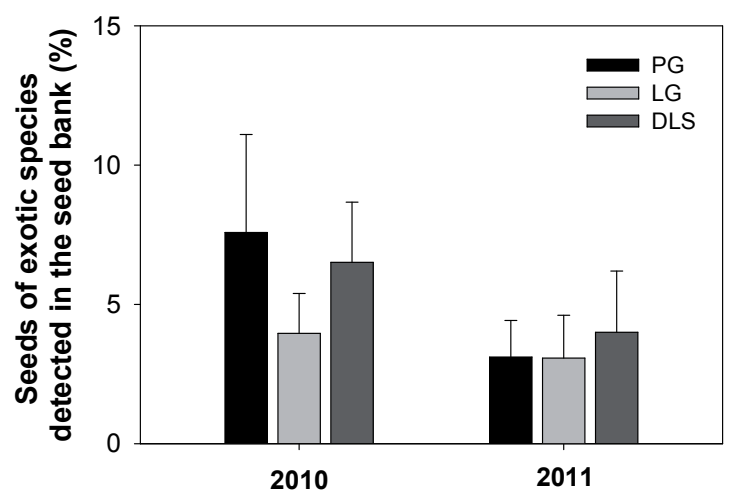

Figure 4. Percentage of seeds with exotic species detected in each sampling plot of the three remnant forests in 2010 and 2011.

accumulated in the upper 0-5 cm soil layer (data not shown). Also, the proportion of the tree species Importance Value (IV) of the seed banks in the studied forests was low, and with values were relatively high in the PG forest and the LG forest compared to the DLS forest for both years.

In the forest seed banks, the species representing the highest IV was different among life forms (Appendix). For example, in both sampling years, the grass Cyperus rotundus occupied the highest IV among all the detected species in the PG forest seed banks. The herbs Pilea microphylla and Hedyotis corymbosa were the species of the greatest IV in the seed banks of the DLS forest in 2010 and 2011, respectively. In the LG forest, the herbaceous species Oxalis corniculata and the tree species $C$. concinna had the highest IV in the seed banks in 2010 and 2011, respectively (Appendix).

A total of 84 seeds belonging to nine exotic species were found in the soil seed banks of all the three forests in 2010 and 2011. Most of the exotic species (7 species) were herbs (Appendix). For each sampling year, seed abundance of exotic species was relatively higher in the PG forest compared to the other two forests. However, there were no significant differences in the percentage of exotic species seeds in the seed banks among the three forests in both years (Fig. 4). Most of the species in the seed banks were characterized with wind or gravity dispersal mode (Fig. 5). The proportion in the number of species with gravity dispersal mode in the PG and LG forest seed banks was much higher than that in the DLS forest, and the opposite trend was observed for the species with animal dispersal mode in both sampling years (Fig. 5).

\section{Floristic similarity between the seed bank and aboveground vegetation}

A total of 46, 64, and 120 species were found in the aboveground vegetation in the PG, LG, and DLS forests, respectively. In all the remnant forests, species richness of the aboveground vegetation was much higher compared to that in the soil seed banks. Many species present in the aboveground vegetation, especially the woody species were absent from the seed banks. Meanwhile, most of the herbs and grasses found in the seed banks did not appear in the standing vegetation. Hence, in each forest, the number of common species appeared in both the seed banks and the aboveground vegetation was low (Table 2). Accordingly, the Sorensen similarity index was low across the three forests, and the values were relatively low in the DLS forest compared to the PG forest and the LG forest (Table 2).

\section{Discussion}

Seed bank size and composition of the remnant forests under urban settings

The seed bank densities in the three studied remnant forests (ranging from 156 to 1181 seeds $\mathrm{m}^{-2}$ ) were much higher than that found in the natural evergreen broad-leaved forests at Dinghushan Natural Reserve within the studied region (Wei et al. 2005). However, the seed bank sizes were relatively small compared with that previously reported for the urban forests elsewhere. For example, the mean number of emergents from the soil in the deciduous forest in New York City was much higher, ranging from 4636 to 5373 seeds m-2 (Kostel-Hughes et al. 1998). 
Table 2. Similarity in species composition between the soil seed banks and corresponding aboveground vegetation of the three remnant forests in 2010 and 2011.

\begin{tabular}{lccccccc}
\hline Forests & $\begin{array}{c}\text { Number of spe- } \\
\text { cies in vegetation }\end{array}$ & \multicolumn{2}{c}{$\begin{array}{c}\text { Number of species in seed } \\
\text { banks }\end{array}$} & \multicolumn{2}{c}{$\begin{array}{c}\text { Number of common species in } \\
\text { both vegetation and seed banks }\end{array}$} & $\begin{array}{c}\text { Sorensen similarity index } \\
(\%)\end{array}$ \\
\cline { 3 - 8 } & & 2010 & 2011 & 2010 & 2011 & 2010 \\
\hline PG & 46 & 32 & 39 & 5 & 6 & 12.8 & 14.1 \\
LG & 64 & 26 & 37 & 5 & 8 & 11.2 \\
DLS & 120 & 25 & 29 & 6 & 7 & 8.3 \\
\hline
\end{tabular}
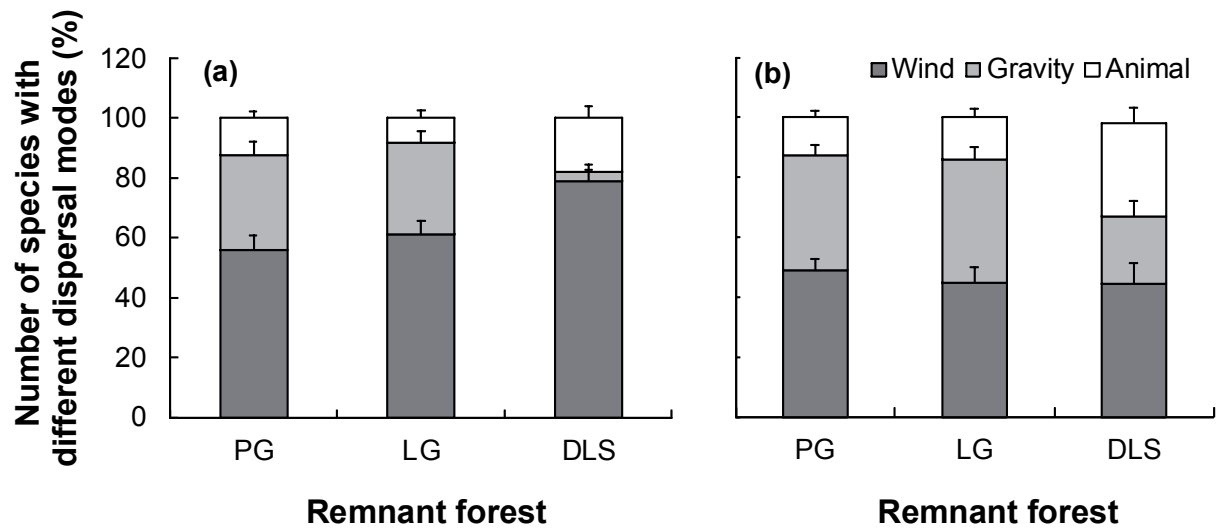

Figure 5. Proportion in number of species with different dispersal modes in the soil seed banks of the three remnant forests in 2010 (a) and 2011 (b).

Similarly to the findings by Kostel-Hughes et al. (1998), the prevailing life form in the soil seed banks of the three forests we examined were herbs and grasses, and only a small proportion of seed abundance, species richness and the Importance Value for tree species. Meanwhile, seed abundance and number of species generally decrease with the soil depth, especially the seeds of tree species accumulated in the upper 0-5 cm soil layers. For example, seeds of Castanopsis lamontii in the DLS forest and Cryptocarya concinna in the LG forest characterized by their large sizes (seed masses) were found on the soil surface. The predominance of herbaceous and weedy species may be attributed to small seed size, which makes them more easily incorporated into the soil to form seed bank and also less prone to predation (Guo et al. 1998, Luzuriaga et al. 2005). Persistence of a seed bank and the seed vertical distribution could be related to the intrinsic physiological responses of species. Previous researches have indicated that seeds of non-woody species can be dormant for a long time under unfavorable environmental conditions, while the tree species with large seed masses easily tend to be rotten or germinate soon after seed fall (Decocq et al. 2004, Daws et al. 2005).

\section{Comparison of seed banks among the remnant forests under} urbanization

Compared to that in the PG and DLS forests, the soil seed banks in PG forest have a relatively high seed abundance and species richness for each life form. Such observation may be due to the difference in standing leaf litter biomass on the ground among the forests. Previous studies have indicated that seed germination or storage in the field is particularly sensitive to litter accumulation (Facelli and Pickett 1991, Rotundo and Aguiar 2005, Miglécz et al. 2013). In our study, the PG forest has a much higher standing litter biomass, and seeds stored in the soil or on the surface might not germinate successfully. Meanwhile, the coverage of large amount of litter may also reduce the predation of seeds especially the tree species which with relatively large seed sizes (Cintra 1997, Reed et al. 2006), thereby increasing the seed abundance in the soil seed banks. In addition, animal community composition may differ among the forests under different urbanization levels, and such variations are always associated with changes in seed removal or post-dispersal seed predation rates that influence the soil seed bank composition. For example, PérezRamos and Marañón (2008) found that the rodent populations and activity increased in microhabitats with dense vegetation and increased seed consumption. In our study, the DLS forest in the rural area is much more diverse and has denser vegetation compared to the PG forest under high urbanization level (Huang et al. 2013). The vegetation composition patterns may partly explain the seed bank composition patterns among the studied forests in terms of seed predation. Also, seed bank composition patterns could be corroboratively evidenced by the observation from our study that the proportion in the number of species with animal dispersal mode in the seed banks was much higher in the DLS forest. 
Across the three remnant evergreen broad-leaved forests Sorensen similarity was low. Such results are consistent with previous researches which have also found poor similarity in species composition between standing vegetation and belowground soil seed banks in forests (Augusto et al. 2001, Hopfensperger 2007). Most woody species appear only in aboveground vegetation but not in the seed banks. In contrast, many herbs and grasses such as Torenia biniflora and Digitaria sanguinalis are stored in the soil but absent from the standing vegetation. As indicated by Daïnou et al. (2011), the contribution of soil seed banks to the resilience of the remnant forests is low. Previous researches have determined that similarity in species composition between the aboveground vegetation and the seed banks is related to disturbance intensity, but these findings are inconsistent (Amrein et al. 2005, Dölle and Schmidt 2009). In our study, the Sorensen similarity index in the DLS forest located at less disturbed areas was relatively low. Such results agree with Dölle and Schmidt (2009) who indicate the difference between seed bank composition and aboveground vegetation decrease with increasing disturbance intensity.

\section{Regeneration potential of the soil seed banks}

Restoration and active management of the remnant forests in the urban settings are critical, and understanding the factors influencing natural regeneration is central to longterm sustainability and preservation (Miller and Hobbs 2002). An important question on sustainable forestry concerns the potential role of soil seed bank in the conservation of forests submitted to disturbance (Lindner 2009). Most of the seeds detected in the seed banks accumulate in the upper soil layer, especially for the tree species, suggesting that the transient seed banks occur in the current urban remnant forests. Although in the LG forest, the dominant species in the standing vegetation occupy high Importance Value in the seed banks, the IVs are generally low for tree species.

Due to the low IV of the tree species in the seed banks and low similarity in species composition between the seed banks and the aboveground vegetation in the remnant forests under urban settings, the soil seed banks could only make a limited contribution to vegetation regeneration. Such findings are dissimilar with previous research conducted in New York City which indicates that the forest soil seed banks have great potential in plant recruitment (Kostel-Hughes et al. 1998). Hence, active silvicultural practices in regenerating the plant communities under urban settings should not be simply relied on the existing soil seed banks.

Several studies suggest that forest regeneration potential from soil seed banks is linked to disturbance history. For example, Martins and Engel (2007) found that, in the less disturbed tropical forest fragments, soil seed banks have a higher potential for regeneration. However, our result was not consistent with such findings. Specifically, in the DLS forest with less anthropogenic disturbance, soil seed bank characteristics such as seed density, species richness, the proportion of tree species dominance and Sorensen similarity between aboveground vegetation and seed banks were relatively low, compared with the PG and LG forests under high urbanization level.

\section{Conclusions}

A better understanding of soil seed bank composition will increase our knowledge of vegetation dynamics, and will be essential for developing appropriate forest restoration strategies and for biodiversity conservation (Ma et al. 2010). Our findings indicate that soil seed bank density, species richness, the proportion of the tree species Importance Value index (IV), and also the species correspondence between seed bank and extant standing vegetation differed significantly in the studied remnant natural forests. Based on what we have learned from the remnant evergreen broad-leaved forests under urbanization, we would conclude that the current soil seed banks could not be considered as important seed sources in forest regeneration and are clearly not sufficient for longterm maintaining forest species diversity, which was similar to the findings in previous studies (e.g., Valkó et al. 2011). Successful forest regeneration may have to rely on the seed rains from the standing vegetation or seed dispersal from the surrounding vegetation, or from transplanting target species seedlings. Further studies on such aspects are needed to better assess the contributions of various regeneration sources in overall forest development. Moreover, because the regeneration potential from the soil seed banks is limited, conservation of the extant vegetation should be the first priority.

Acknowledgements. This study was supported by the National Natural Science Foundation of China (31100469, 41301058) and Key Laboratory of Vegetation Restoration and Management of Degraded Ecosystems, Chinese Academy of Sciences. The authors are indebted to D. Liu and Y. Tong of South China Botanical Garden for identifying the species germinated from the soil samples, and H. Zhang for laboratory work.

\section{References}

Amrein, D., H. Rusterholz and B. Baur. 2005. Disturbance of suburban Fagus forest by recreational activities: Effects on soil characteristics, above-ground vegetation and seed bank. Appl. Veg. Sci. 8: 175-182.

Augusto, L., J.L. Dupouey, J.F. Picard and J. Ranger. 2001. Potential contribution of the seed bank in coniferous plantations to the restoration of native deciduous forest vegetation. Acta Oecol. 22: 87-98.

Bertoncini, A.P. and R.R. Rodrigues. 2008. Forest restoration in an indigenous land considering a forest remnant influence (Avai, Sao Paulo State, Brazil). Forest Ecol. Manag. 255: 513-521.

Bossuyt, B. and O. Honnay. 2008. Can the seed bank be used for ecological restoration? An overview of seed bank characteristics in European communities. J. Veg. Sci. 19: 875-884.

Broshot, N.E. 2007. The influence of urbanization on forest stand dynamics in Northwestern Oregon. Urban Ecosyst. 10: 285-298. 
Burton, M.L. and L.J. Samuelson. 2008. Influence of urbanization on riparian forest diversity and structure in the Georgia Piedmont, US. Plant Ecol. 195: 99-115.

Cintra, R. 1997. Leaf litter effects on seed and seedling predation of the palm Astrocaryum murumuru and the legume tree Dipteryx micrantha in Amazonian forest. J. Trop. Ecol. 13: 709-725.

Cox, G.W. 1985. Laboratory Manual of General Ecology. McGrawHill, New York.

Daïnou, K., A. Bauduin, N. Bourland, J. Gillet, F. Fétéké and J. Doucet. 2011. Soil seed bank characteristics in Cameroonian rainforests and implications for post-logging forest recovery. Ecol. Eng. 37: 1499-1506.

Daws, M.I., N.C. Garwood and H.W. Pritchard. 2005. Traits of recalcitrant seeds in a semi-deciduous tropical forest in Panama: some ecological implications. Funct. Ecol. 19: 874-885.

Decocq, G., B. Valentin, B. Toussaint, F. Hendoux, R. Saguez and J. Bardat. 2004. Soil seed bank composition and diversity in a managed temperate deciduous forest. Biodivers. Conserv. 13: 2485-2509.

Ding, S.Y. and Y.C. Song. 2004. Research advances in vegetation dynamic of evergreen broad-leaved forest. Acta Ecol. Sin. 24: 1769-1779.

Dölle, M. and W. Schmidt. 2009. The relationship between soil seed bank, above-ground vegetation and disturbance intensity on oldfield successional permanent plots. Appl. Veg. Sci. 12: 415-428.

Dwivedi, P., C.S. Rathore and Y. Dubey. 2009. Ecological benefits of urban forestry: The case of Kerwa Forest Area (KFA), Bhopal, India. Appl. Geogr. 29: 194-200.

Editorial Committee of Forests of Guangdong. 2005. Guangdong Yearbook. Guangdong Yearbook Publishing House, Guangzhou.

Facelli, J. and S.T.A. Pickett. 1991. Plant litter: its dynamics and effects on plant community structure. Bot. Rev. 57: 1-32.

Grimm, N.B., S.H. Faeth, N.E. Golubiewski, C.L. Redman, J. Wu, X. Bai and J.M. Briggs. 2008. Global change and the ecology of cities. Science. 319: 756-760.

Guo, Q.F., P.W. Rundel and D.W. Goodall. 1998. Horizontal and vertical distribution of desert seed banks: patterns, causes, and implications. J. Arid Environ. 38: 465-478.

Heyman, E. 2010. Clearance of understory in urban woodlands: Assessing impact on bird abundance and diversity. Forest Ecol. Manag. 260: 125-131.

Hill, S.J. and K. French. 2003. Response of the soil seed-bank of Cumberland Plain Woodland to heating. Austral. Ecol. 28: 14 22.

Hopfensperger, K.N. 2007. A review of similarity between seed bank and standing vegetation across ecosystems. Oikos 116: 14381448.

Huang, L., W. Zhu, H. Ren, H. Chen and J. Wang, 2012. Impacts of atmospheric nitrogen deposition on soil properties and herblayer diversity in remnant forests along an urban-rural gradient in Guangzhou, southern China. Plant Ecol. 213: 1187-1202.

Huang, L., H. Chen, H. Ren, J. Wang and Q. Guo. 2013. Effects of urbanization on the structure and functional traits of remnant subtropical evergreen broad-leaved forests in South China. Environ. Monit. Assess. 185: 5003-5018.

Koncz, G., P. Török, M. Papp, G. Matus and B. Tóthmérész. 2011. Penetration of weeds into the herbaceous understorey and soil seed bank of a Turkey oak-sessile oak forest in Hungary. Community Ecol. 12: 227-233.

Kostel-Hughes, F., T.P. Young and M.J. McDonnell. 1998. The soil seed bank and its relationship to the aboveground vegetation in deciduous forests in New York City. Urban Ecosys. 2: 43-59.
Leinonen, T., R. Sungurov, T. Kolstrom, A. Sokolov, A. Zigunov and A.Dorosin. 2008. Forest regeneration in Northern and Northwestern Russia in 1993-2004 - Methods, results and development needs. Forest Ecol. Manag. 255: 383-395.

Lindner, A. 2009. A rapid assessment approach on soil seed banks of Atlantic forest sites with different disturbance history in Rio de Janeiro, Brazil. Ecol. Eng. 35: 829-835.

Luzuriaga, A.L., A. Escudero, J.M. Olano, and J. Loidi. 2005 Regenerative role of seed banks following an intense soil disturbance. Acta Oecol. 27: 57-66.

Ma, M., X. Zhou and G. Du. 2010. Role of soil seed bank along a disturbance gradient in an alpine meadow on the Tibet plateau. Flora 205: 128-134.

Maron, J.L. and E.L. Simms. 1997. Effect of seed predation on seed bank size and seedling recruitment of bush lupine (Lupinus arboreus). Oecologia 111: 76-83.

Martins, A.M. and V.L. Engel. 2007. Soil seed banks in tropical forest fragments with different disturbance histories in southeastern Brazil. Ecol. Eng. 31: 165-174.

Miglécz, T., B. Tóthmérész, O. Valkó, A. Kelemen and P. Török. 2013. Effects of litter on seedling establishment: an indoor experiment with short-lived Brassicaceae species. Plant Ecol. 214: 189-193.

Miller, J.R. and R.J. Hobbs. 2002. Conservation where people live and work. Conserv. Biol. 16: 330-337.

Pérez-Ramos, I.M. and T. Marañón. 2008. Factors affecting post-dispersal seed predation in two coexisting oak species microhabitat, burial and exclusion of large herbivores. Forest Ecol. Manag. 255: 3506-3514

Pedlowski, M.A., V.A.C. Da Silva, J.J.C. Adell and N.C. Heynen. 2002. Urban forest and environmental inequality in Campos dos Goytacazes, Rio de Janeiro, Brazil. Urban Ecosyst. 6: 9-20.

Pellissier, V., F. Rose, R. Aguejdad, H. Quenol and P. Clergeau. 2008 Relationships between soil seed bank, vegetation and soil fertility along an urbanization gradient. Appl. Veg. Sci. 11: 325-334.

Reed, A.W., G.A. Kaufman and D.W. Kaufman. 2006. Effect of plant litter on seed predation in three prairie types. Am. Midl. Nat. 155: 278-285.

Rotundo, J.L. and M.R. Aguiar. 2005. Litter effects on plant regeneration in arid lands: a complex balance between seed retention, seed longevity and soil-seed contact. J. Ecol. 93: 829-838.

Shannon, C.E. 1948. A mathematical theory of communication. Bell Syst. Tech J. 27: 379-423.

Smith, R.S., R.S. Shiel, D. Millward, P. Corkhill and R.A. Sanderson. 2002. Soil seed banks and the effects of meadow management on vegetation change in a 10-year meadow field trial. J. Appl. Ecol. 39: 279-293.

Ter Heerdt, G.N.J., G.L. Verweij, R.M. Bekker and J.P. Bakker. 1996. An improved method for seed bank analysis: seedling emergence after removing the soil by sieving. Funct. Ecol. 10: 144-151.

Valkó, O., P. Török, B. Tóthmérész and G. Matus. 2011. Restoration potential in seed banks of acidic fen and dry-mesophilous meadows: Can restoration be based on local seed banks? Restor. Ecol. 19: 9-15

Wang, J., H. Ren, L. Yang, D. Li and Q. Guo. 2009. Soil seed bank in four 22-year-old plantations in South China: Implications for restoration. Forest Ecol. Manag. 258: 2000-2006.

Wang, J., D. Li, H. Ren and L. Yang. 2010. Seed supply and the regeneration potential for plantations and shrubland in southern China. Forest Ecol. Manag. 259: 2390-2398.

Wang, X.H., E.R. Yan, X. Yan and L.Y. Wang. 2005. Analysis of degraded evergreen broad-leaved forest communities in Eastern 
China and issue in forest restoration. Acta Ecol. Sin. 25: 17961803 .

Wei, S.G., L. Li, Z.L. Huang, S.J. Peng and J.H. Shi. 2005. Study on the dynamic of seed bank of Dinghushan forest soil. Ecol. Environ. 14: 917-920.

Wu, C.Y. and P.H. Raven. 1994. Flora of China. Science Press, Beijing.

Received June 30, 2014

Revised August 24, 2014 Accepted October 15, 2014

\section{Electronic Appendix}

Species composition, the number of germinated seedlings and the species Importance Value index (IV, \%) in the soil seed banks of the three remnant forests in 2010 and 2011.

The file may be downloaded from www.akademiai.com. 